\title{
Differential metabolism of exogenous platelet-activating factor by glandular epithelial and stromal cells of rabbit endometrium
}

\author{
G. B. Kudolo ${ }^{1}$, Y-Q. Yang ${ }^{2}$, D-B. Chen ${ }^{3}$, M. A. Jones ${ }^{4}$ and \\ M. J. K. Harper ${ }^{3 *}$ \\ ${ }^{1}$ Department of Clinical Laboratory Sciences, School of Allied Health Sciences, University of Texas Health \\ Science Center, San Antonio, TX 78284, USA; ${ }^{2}$ Department of Medicine, University of Texas Health \\ Science Center at San Antonio, TX 78284, USA; ${ }^{3}$ Department of Obstetrics and Gynecology, Baylor \\ College of Medicine, 6550 Fannin St, Suite 821A. Houston. TX 77030, USA; and ${ }^{4}$ Department of \\ Chemistry, Illinois State University, Normal, IL 61790, USA
}

\begin{abstract}
Significant changes in platelet-activating factor (PAF; 1-O-alkyl-2-acetyl-sn-glycero-3phosphorylcholine) concentration have been observed in rabbit endometrium during the preimplantation period, but, under in vitro conditions, constitutive PAF biosynthesis by isolated endometrial tissues was not easily demonstrable. Relative changes in enzymes involved in the synthesis and metabolism of PAF in the tissues may account for this disparity. In addition, during this period of preimplantation, marked changes in PAF receptor concentration have been noted. The present study examines the factors that may modulate the metabolism of exogenous $\left[{ }^{3} \mathrm{H}\right] \mathrm{PAF}$ in the endometrium of rabbits on day 6 of pregnancy. Since preferential $\left[{ }^{3} \mathrm{H}\right] \mathrm{PAF}$ binding in situ by the glandular epithelial, but not by the stromal, cells was demonstrated, their cell-specific metabolism of exogenous $\left[{ }^{3} \mathrm{H}\right] \mathrm{PAF}$ was also examined. After entry into the endometrial cell, [ $\left.{ }^{3} \mathrm{H}\right] \mathrm{PAF}$ was rapidly metabolized by the sequential action of cytosolic $\mathrm{Ca}^{2+}$-independent acetylhydrolase to $\left[{ }^{3} \mathrm{H}\right]$ lyso-PAF and this was in turn acylated by membrane-associated transacylase to $\left[{ }^{3} \mathrm{H}\right]$ alkylacylglycerylphosphorylcholine. PAF resynthesis was not observed and, in stromal cells, there was a significant build-up of $\left[{ }^{3} \mathrm{H}\right]$ lyso-PAF, suggesting that lyso-PAF:acetyl-CoA acetyltransferase may be a limiting factor. In the glandular epithelial cells, however, there was a significant accumulation of a neutral lipid without a significant build-up of $\left[{ }^{3} \mathrm{H}\right]$ lyso-PAF or $\left[{ }^{3} \mathrm{H}\right] \mathrm{PAF}$. The neutral lipid co-migrated with the product of phospholipase C-catalysed metabolism of PAF and authentic 1-O-hexadecyl-2-acetyl-glycerol. In addition, the elution times of phospholipase $\mathrm{C}$ digestion of C18 PAF and the neutral lipid produced by cellular metabolism of $\left[{ }^{3} \mathrm{H}\right] \mathrm{PAF}$, determined by gas chromatography/flame ionization detection, were similar. It seems that it is the synthesis of the neutral lipid from reacetylated $\left[{ }^{3} \mathrm{H}\right]$ lyso-PAF that prevented $\left[{ }^{3} \mathrm{H}\right] \mathrm{PAF}$ accumulation under in vitro conditions. This is the first documentation of the synthesis of this lipid in the mammalian uterus. The lipid may serve as the precursor for de novo PAF synthesis in the glandular epithelial cells during endometrial proliferation.
\end{abstract}

\section{Introduction}

Platelet-activating factor (PAF), chemically identified as $1-O$ alkyl-2-acetyl-sn-glycero-3-phosphorylcholine, is a very potent ether-linked phospholipid with a wide spectrum of biological and pathophysiological activities (Snyder et al., 1989; Snyder, 1990). A variety of cells can synthesize PAF upon stimulation, and PAF has been implicated in a number of reproductive

${ }^{*}$ Reprint requests.

Received 12 May 1995. phenomena (Harper, 1989), including sperm motility (Ricker et al., 1989), ovulation (Abisogun et al., 1989), fertilization (O'Neill, 1987), implantation and early development of the embryo (O'Neill et al., 1987, 1988). Platelet-activating factor has been detected in the uterus of rats (Yasuda et al., 1986) and rabbits (Angle et al., 1988), and separated human endometrial cells (Alecozay et al, 1989). It may be biosynthesized via either the de novo pathway (Lee et al., 1986, 1988; Blank et al., 1988) from the immediate precursor 1-O-alkyl-2-acetyl-glycerol via a dithiothreitol (DTT)-insensitive cholinephosphotransferase, which is thought to be responsible for maintaining endogenous 
physiological concentrations of PAF (constitutive expression), or by the 'remodelling' pathway (Wykle et al., 1980; Uemura et al., 1991) in which it is activated in inflammatory states by deacylation of pre-existing 1-O-alkyl-2-acyl-sn-glycero-3phosphorylcholine (alkylacyl-GPC) by phospholipase $\mathrm{A}_{2}$, which produces lyso-PAF, which in turn is rapidly acetylated to PAF. In many circumstances PAF is not released from the cells but remains cell-associated.

Knowledge of the PAF metabolic pathways is derived from studies with different cells from various species (Robinson et al., 1985: Touqui et al., 1985). For a target cell responding to an exogenous PAF molecule, the following would appear to be the sequence of events: PAF penetration into the outer plasma membrane, upon which (i) complexing with specific membrane receptors may promote cell activation to perform diverse receptor-mediated biological responses (Hwang et al., 1989), and (ii) PAF may be subject to membrane-bound PAFmetabolizing enzymes that degrade the phospholipid (Lachachi et al., 1985; Snyder et al., 1986; Kudolo and Harper, 1989, 1990). The PAF molecule, which is internalized intact, may also be transported into the cell, traversing the cytosol where PAF may be metabolized. During passage through the cell membrane, PAF may be converted to lyso-PAF before reacylation to alkylacyl-GPC (see Kudolo and Harper, 1989, 1990 for references). These two metabolites are important precursors for PAF biosynthesis. Other than our studies with purified rabbit endometrial membranes (Kudolo and Harper, 1989, 1990), in which the attempts made were solely to control exogenous PAF metabolism during measurement of PAF receptors, there are no reports of the fate of exogenous PAF in rabbit uterus. This information is important because significant concentrations of uterine PAF are demonstrable in the rabbit, reaching a peak (a more than 15-fold increase over oestrous concentrations) on day 5 of pregnancy (Angle et al., 1988). Unlike human endometrial cells, however, constitutive PAF synthesis in separated rabbit endometrial cells in vitro is not easily detectable; significant synthesis is observed only after cell activation by pulsing with the calcium ionophore A23187 (Kasamo et al., 1992). Relative changes in enzymes in the synthesis and metabolism of PAF may account for the changes in endogenous uterine PAF during the preimplantation period of pregnancy and the inability to observe significant PAF accumulation in endometrial cells during in vitro incubation. The object of the present study was to examine some of the factors controlling the metabolism of exogenous $\left[{ }^{3} \mathrm{H}\right] \mathrm{PAF}$ in endometrial cells of rabbits on day 6 of pregnancy, since this was the day on which PAF concentrations decrease markedly.

\section{Materials and Methods}

\section{Materials}

The radioligands, $\left.\quad 1-O-l^{3} \mathrm{H}\right]$ octadecyl-2-acetyl-sn-glycero3-phosphorylcholine (114-184 Ci per mmol) and $\mathrm{I}-\mathrm{O}$ $\left[{ }^{3} \mathrm{H}\right]$ hexadecyl-2-lyso-sn-glycero-3-phosphorylcholine (110 Ci per mmol) were obtained from Amersham International (Arlington Heights, IL) (purity >97\%) and were used without further purification. Carbamyl-PAF (1-O-alkyl-2-Nmethylcarbamyl-sn-glycero-3-phosphocholine) was purchased from Calbiochem (La Jolla, CA). Sigma Chemical Co. (St Louis, $\mathrm{MO}$ ) supplied reagent grade of most of the chemicals used, including PAF (octadecyl; C18 PAF), lyso-PAF (hexadecyl; C16 lyso-PAF), 1-O-hexadecyl-sn-glycerol (chimyl alcohol), 1-O-hexadecyl-2-acetyl-rac-glycerol, sphingomyelin, egg yolk phosphatidylcholine, fraction $\mathrm{V}$ and fatty-acid-free bovine serum albumin and phospholipase $\mathrm{C}$ (from $C$. welchii). Tertbutyldimethylchlorosilyl/imidazole (TBDMSI) reagent was from Alltech Applied Science (Deerfield, IL). Diisopropyl fluorophosphate (DFP) was from Aldrich Chemical Company (Milwaukee, WI). Silica Gel G plates $(250 \mu \mathrm{m} ; 20 \mathrm{~cm} \times 20 \mathrm{~cm})$ were obtained from Analtech (Newark, DE).

\section{Animals}

Mature New Zealand White-Cambridge female rabbits (Oryctolagus cuniculus) (body mass $>3.0 \mathrm{~kg}$ : Penn Acres, Wimberley, TX) were caged individually in a controlled environment under a photoperiod of $14 \mathrm{~h}$ light: $10 \mathrm{~h}$ dark, fed $170 \mathrm{~g}$ rabbit pellets per day and individually provided with water ad libitum. Rabbits in oestrus were inseminated with $0.5 \mathrm{ml}$ of fresh mixed sperm suspension (collected via an artificial vagina from fertile bucks) followed by i.v. injection of 50 iu of hCG (Ayerst Laboratories, New York, NY) and designated as at day 0 of pregnancy. On day 6 of pregnancy, the animals were killed with an i.v. overdose of sodium pentobarbital. The uterine tissues were quickly removed (extraneous fat and mesenteries were excised and excess blood was blotted off), and then washed in ice-cold Tris- $\mathrm{HCl}$ buffer $\left.(50 \mathrm{mmol} \mathrm{l})^{-1}, \mathrm{pH} 7,4^{\circ} \mathrm{C}\right)$. The uterine horns were opened at the mesometrial junction and the endometrial tissues were harvested into fresh Tris buffer by scraping with a glass microscope slide. Contaminating blood and its constituents were removed by allowing the endometrial cells to sediment at unit gravity. This washing procedure was repeated twice before resuspension in 10 volumes of Tris buffer. Portions of the cell suspension were added to $16 \mathrm{ml}$ polypropylene tubes (with snap caps) and sedimented by centrifugation at $800 \mathrm{~g}$ for $10 \mathrm{~min}$ at $4^{\circ} \mathrm{C}$. Each tube contained approximately $30 \mathrm{mg}$ of endometrial tissues and the cellular content of the preparations was computed by estimating the total DNA per tube subsequent to the extraction of lipids as described below.

\section{Whole cell incubations}

Endometrial tissues were suspended in $50 \mathrm{mmol}$ Tris- $\mathrm{HCl}$ buffer $\mathrm{I}^{-1}$ ( $\mathrm{pH} \mathrm{7.4)}$ and incubated at $37^{\circ} \mathrm{C}$ for $60 \mathrm{~min}$ without any additions (control) or with various concentrations of carbamyl-PAF. After the incubations, the cell suspensions were centrifuged for $10 \mathrm{~min}$ at $500 \mathrm{~g}$ and the cells resuspended in the original volume of buffer. The cell suspensions were used for whole cell incubation with tritiated ligands: $0.5 \mathrm{ml}$ aliquots of the endometrial tissue suspensions were added to $0.5 \mathrm{ml}$ solution containing various additives (as described in the legends and figures) and $0.5 \mathrm{ml}\left[{ }^{3} \mathrm{H}\right] \mathrm{PAF}(5 \mu \mathrm{Ci})$ or $\left[{ }^{3} \mathrm{H}\right] l y s \mathrm{~s}-$ PAF $(5 \mu \mathrm{Ci})$ and incubated for $15 \mathrm{~min}$ at $37^{\circ} \mathrm{C}$. Incubations were carried out in snap-capped polypropylene tubes. The lipids were extracted by a modification of the procedure of Bligh and Dyer (1959). Briefly, the reactions were terminated 
by addition of $6 \mathrm{ml}$ of a mixture of chloroform and $2 \%(\mathrm{v} / \mathrm{v})$ acetic acid in methanol (1:2) after adjusting the aqueous volume to $1.6 \mathrm{ml}$. The monophasic solution was vortexed at $15 \mathrm{~min}$ intervals for $1 \mathrm{~h}$ at room temperature. Thereafter, $2 \mathrm{ml}$ chloroform and $2 \mathrm{ml}$ water were added to each tube, vortexed and centrifuged at $500 \mathrm{~g}$ for $10 \mathrm{~min}$ to effect separation of the aqueous and organic phases. The chloroform phase was removed and the aqueous layer washed twice, each time with $4 \mathrm{ml}$ chloroform, pooling all the chloroform extracts. The aqueous layer was made up to $0.2 \mathrm{~mol}$ perchloric acid (PCA) $\mathrm{1}^{-1}$, vortexed and centrifuged at $1000 \mathrm{~g}$ for $10 \mathrm{~min}$ at $4^{\circ} \mathrm{C}$ to remove the cellular pellets. The cellular pellets were washed

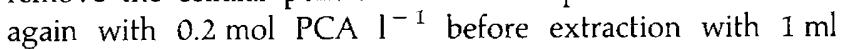

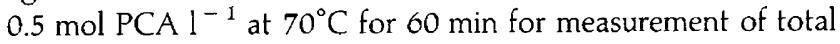
cellular DNA, according to the procedure of Burton (1956). The DNA content of a known number of endometrial cells (isolated as described below) was determined. Each cell was estimated to contain approximately 10 pg DNA and was used to estimate the number of cells in tissue suspensions.

\section{$\left.{ }_{[3}^{3} \mathrm{H}\right]$ Platelet-activating factor uptake into the endometrial cell}

To examine the time course of $\left[{ }^{3} \mathrm{H}\right] \mathrm{PAF}$ entry into the endometrial cells, the endometrial cells were isolated as described above and resuspended in $20 \mathrm{ml}$ Tris- $\mathrm{HCl}$ buffer, $\mathrm{pH} 7.4$, and incubated with $50 \mu \mathrm{Ci}\left[{ }^{3} \mathrm{H}\right] \mathrm{PAF}$. After $5,15,30,45$ and $60 \mathrm{~min}, 2 \mathrm{ml}$ aliquots were taken in duplicate and centrifuged at $1000 \mathrm{~g}$ for $10 \mathrm{~min}$ at $4^{\circ} \mathrm{C}$. The supernatants were removed and $500 \mu \mathrm{l}$ aliquots taken in triplicate for measurement of radioactivity. The pellets were washed with $\mathrm{Tris}-\mathrm{HCl}$ buffer containing $0.25 \%(\mathrm{w} / \mathrm{v}) \mathrm{BSA}$ twice and finally with Tris- $\mathrm{HCl}$ buffer, each time taking $500 \mu \mathrm{l}$ aliquots in triplicate for liquid scintillation counting. The cell pellets were then suspended in $2 \mathrm{ml}$ Tris- $\mathrm{HCl}$ buffer and homogenized in a glass-to-glass Dounce tissue grinder with four strokes. The homogenate was centrifuged at $1000 \mathrm{~g}$ for $10 \mathrm{~min}$. The pellet was resuspended in $2 \mathrm{ml}$ buffer and $500 \mu \mathrm{l}$ aliquots in triplicate were taken for liquid scintillation counting. The supernatant was removed and centrifuged at $30000 \mathrm{~g}$ for $30 \mathrm{~min}$ to isolate the plasma membranes and the cytoplasmic fractions. The membrane pellet was resuspended in $2 \mathrm{ml}$ Tris- $\mathrm{HCl}$ buffer and $500 \mu \mathrm{l}$ aliquots of this suspension and the cytoplasmic fraction (supernatant) were taken in triplicate for liquid scintillation counting.

\section{Cell separation and culture}

The isolation of stromal and glandular cells for culture was achieved by aseptic digestion of uterine tissues from animals at day 6 of pregnancy according to a modified procedure of Ricketts et al. (1983). Briefly, each uterine horn was washed four times with $10 \mathrm{ml}$ incomplete (without $\mathrm{Ca}^{2+}$ and $\mathrm{Mg}^{2+}$ ) Dulbecco's PBS before it was slit open at the longitudinal margin. After one additional washing with $10 \mathrm{ml}$ PBS, each uterine horn was incubated in $6.25 \mathrm{ml}$ PBS containing $2 \%(\mathrm{w} / \mathrm{v})$ pancreatin and $0.5 \%(\mathrm{w} / \mathrm{v})$ trypsin initially for $2 \mathrm{~h}$ at $4{ }^{\circ} \mathrm{C}$, and then for $1 \mathrm{~h}$ at $21^{\circ} \mathrm{C}$. The incubate was vortexed briefly and the cell supernatant transferred to a conical flask containing $0.6 \mathrm{ml}$ of heat inactivated $\left(56^{\circ} \mathrm{C}\right.$, a temperature insufficient to inactivate acetylhydrolase, $30 \mathrm{~min}$ ) fetal calf serum (FCS) and $1.6 \mathrm{ml}$ Medium 199 with Hank's balanced salts (M199 + HBSS) containing $400 \mathrm{U}$ collagenase. The residual uterine tissue was washed twice with $10 \mathrm{ml}$ PBS and all the supernatants pooled and incubated for $30 \mathrm{~min}$ at $37^{\circ} \mathrm{C}$ with shaking. The cell suspension was then filtered through a $350 \mu \mathrm{m}$ nylon mesh to obtain the epithelial cell fraction. The stromal cells were obtained by subjecting the residual uterine tissue to additional enzymatic digestion for $2 \mathrm{~h}$ at $21^{\circ} \mathrm{C}$ in $5 \mathrm{ml}$ PBS containing $0.05 \%(\mathrm{w} / \mathrm{v})$ trypsin, $0.02 \%(\mathrm{w} / \mathrm{v})$ EDTA and $400 \mathrm{U}$ deoxyribonuclease 1 (DNase 1 ), and then incubating for $15 \mathrm{~min}$ at $37^{\circ} \mathrm{C}$ with continuous shaking. The stromal cell suspension was obtained essentially as described for the epithelial cell fraction, except that the cell suspension was filtered through a $35 \mu \mathrm{m}$ nylon mesh. Both the epithelial and stromal cell fractions were washed twice in $25 \mathrm{ml}$ PBS by centrifugation at $500 \mathrm{~g}$ for $10 \mathrm{~min}$ and resuspended in $15 \mathrm{ml}$ basal medium, which consisted of M199 with Earle's salts, penicillin (100000 $\mathrm{U} \mathrm{I}^{-3}$ ), streptomycin (100 $\mathrm{mg} \mathrm{l}^{-1}$ ), sodium pyruvate $\left(1 \mathrm{mmol} \mathrm{l}^{-1}\right.$ ), insulin $\left(5 \mathrm{mg} \mathrm{l}^{-1}\right)$, transferrin $\left(5 \mathrm{mg} \mathrm{l}^{-1}\right)$, selenite $\left(5 \mu \mathrm{gl}^{-1}\right)$ and epidermal growth factor $\left(10 \mu \mathrm{g} \mathrm{l}^{-1}\right)$. Each cell suspension was incubated in Petri dishes in humidified air with $5 \% \mathrm{CO}_{2}$ at $37^{\circ} \mathrm{C}$. After $45 \mathrm{~min}$, the floating cells from the epithelial cell fraction and the sedimented cells from the stromal cell fraction were isolated, and resuspended in 10\% heat-inactivated FCSsupplemented basal medium. The number and viability ( $>95 \%$ at time of plating) of the cells were estimated using a haemocytometer and the trypan blue exclusion test. Viable cell concentration was adjusted to approximately $0.5 \times 10^{6}$ cells $\mathrm{ml}^{-1}$ for epithelial and $0.3 \times 10^{6}$ cells ml ${ }^{-1}$ for stromal cell preparations and $2 \mathrm{ml}$ of the cell suspensions plated per well (35 mm), using 6-well plastic tissue culture plates (Corning Glass Works, Corning, NY). The cells were incubated under standard culture conditions and the culture medium was changed daily. On the second day of culture, after two washes of the cells with warm PBS, the culture medium was changed to serum-free basal medium, but containing $0.25 \%(\mathrm{w} / \mathrm{v}) \mathrm{BSA}$ (Fraction V). Next, $\left.{ }^{3} \mathrm{H}\right] \mathrm{PAF}$ was added to a final concentration of $4 \mathrm{nmol} \mathrm{l}^{-1}$ and the incubation continued for 15,30 and $60 \mathrm{~min}$ (tritiated substrates were first solubilized in minimal volume of $70 \%(\mathrm{v} / \mathrm{v})$ ethanol, as described by Kudolo and Harper, 1990, when over $95 \%$ of $\left[{ }^{3} \mathrm{H}\right] \mathrm{PAF}$ remains in aqueous solution). The medium was removed and $1.5 \mathrm{ml}$ aliquots used for extraction of lipids as described above. The lipids associated with the glandular epithelial cells were also extracted, both before and after incubation with phospholipase $\mathrm{C}$.

\section{Catabolism of platelet-activating factor by phospholipase $C$}

The $\left[{ }^{3} \mathrm{H}\right] \mathrm{PAF}$ and $\left[{ }^{3} \mathrm{H}\right] \mathrm{lyso}-\mathrm{PAF}(5 \mu \mathrm{Ci})$ were added to $200 \mu \mathrm{g}$ of cold PAF and lyso-PAF, dried under a stream of nitrogen gas and solubilized in $0.5 \mathrm{ml} 0.125 \%(\mathrm{w} / \mathrm{v}) \mathrm{BSA}$ in Tris- $\mathrm{HCl}$ buffer (containing $25 \mathrm{mmol} \mathrm{Ca}^{2+} \mathrm{l}^{-1}$ ) and incubated with $10 \mu \mathrm{g}$ phospholipase $\mathrm{C}$ for $1 \mathrm{~h}$ at $37^{\circ} \mathrm{C}$ (Benveniste et al., 1977). The reaction product was extracted by the method of Bligh and Dyer (1959) and resuspended in $0.5 \mathrm{ml}$ chloroform.

\section{Identification of lipids}

Thin layer chromatography. The chloroform lipid extracts, dried under nitrogen gas, were suspended in $0.5 \mathrm{ml}$ chloroform. 
Duplicate $0.05 \mathrm{ml}$ aliquots were quickly taken for liquid scintillation counting for eventual estimation of the recovery rate of the radioactivity, and duplicate $0.2 \mathrm{ml}$ aliquots were taken and redried under nitrogen for chromatography: one was used for the chromatography of phospholipids and the other for neutral lipids, all on Silica Gel G plates. The plates were washed in chloroform:methanol:water (65:35:6) and heat activated at $120^{\circ} \mathrm{C}$, for $3 \mathrm{~h}$ before use. A solvent system consisting of chloroform:methanol:acetic acid:water (50:25:8:4) was used to separate the phospholipids, and at least two of the following authentic compounds were added to the lipid extracts as internal standards: octadecyl-PAF, sphingomyelin, lysophosphatidylcholine, and egg yolk phosphatidylcholine. This solvent system resolved the glycerophosphatides as follows: lysophosphatidylcholine, which co-migrated with hexadecyl$\left[{ }^{3} \mathrm{H}\right]$ lyso-PAF (relative motility $R_{\mathrm{f}}=0.12-0.14$ ), octadecyl-PAF $\left(R_{\mathrm{f}}=0.22-0.27\right)$ and phosphatidylcholine $\left(R_{\mathrm{f}}=0.57-0.60\right)$. In all cases, the TLC plates were exposed to iodine vapour; the separation zones on the plates were divided into $15 \mathrm{Icm}$ zones, noting the fraction numbers of the authentic standards; and each fraction was scraped into $7 \mathrm{ml}$ minivials for liquid scintillation spectrometry after addition of $4 \mathrm{ml}$ of Ready-Protein ${ }^{(m)}$ scintillation cocktail (Beckman Instruments Inc., Fullerton, CA). For correction of radioactivity counts, 100000 d.p.m. of $\left[{ }^{3} \mathrm{H}\right] \mathrm{PAF}$ was added to silica gel scrapings (the same amount as the developed plates) and counted under the same conditions. Neutral lipid products were identified by chromatography of the lipid extracts in a solvent system consisting of chloroform and methanol (98:2) with 1-Ohexadecyl-sn-glycerol $\left(R_{\mathrm{f}}=0.25-0.30\right)$ and 1-O-hexadecyl-2acetyl-rac-glycerol $\left(R_{\mathrm{f}}=0.46-0.55\right)$ as standards. These C16 compounds were used as standards, since the analogous $\mathrm{C} 18$ 1-O-octadecyl-2-acetyl-glycerol is not available.

Gas chromatography-flame ionization detection. Gas chromatography-flame ionization detection (GC/FID) analysis was performed using a Hewlett Packard (HP) 5830A gas chromatograph with FID. The capillary column was an Alltech Econocap Carbowax, $30 \mathrm{~cm} \times 0.53 \mathrm{~mm}$. The standard operating conditions were a starting temperature of $150^{\circ} \mathrm{C}$ held for $4 \mathrm{~min}$, increased by $10^{\circ} \mathrm{C} \mathrm{min}-1$ up to $240^{\circ} \mathrm{C}$ and held at this temperature for $10 \mathrm{~min}$. The injection and FID temperatures were $250^{\circ} \mathrm{C}$. The lipid samples (including the standard C18 PAF - phospholipase C digestion product) were extracted and chromatographed on TLC to separate the lipids co-migrating with authentic PAF and the neutral lipid, 1-O-hexadecyl-2acetyl-rac-glycerol. The lipids were derivatized with TBDMSI, according to the methods of Triolo et al. (1991) and GC performed according to the method of Maggi et al. (1994). Owing to unavailability, authentic 1-O-octadecyl-2-acetylglycerol could not be used as a standard; however, the elution patterns of the phospholipase $\mathrm{C}$ digestion of C18 PAF (which gives rise to 1-O-octadecyl-2-acetyl-glycerol) was compared with that of the neutral lipid derived from metabolism of $\left[{ }^{3} \mathrm{H}\right] \mathrm{PAF}$ by the glandular epithelial cells.

\section{Statistical analysis}

Each value is the mean \pm SEM, usually from the three independent experiments. The ANOVA and Student-

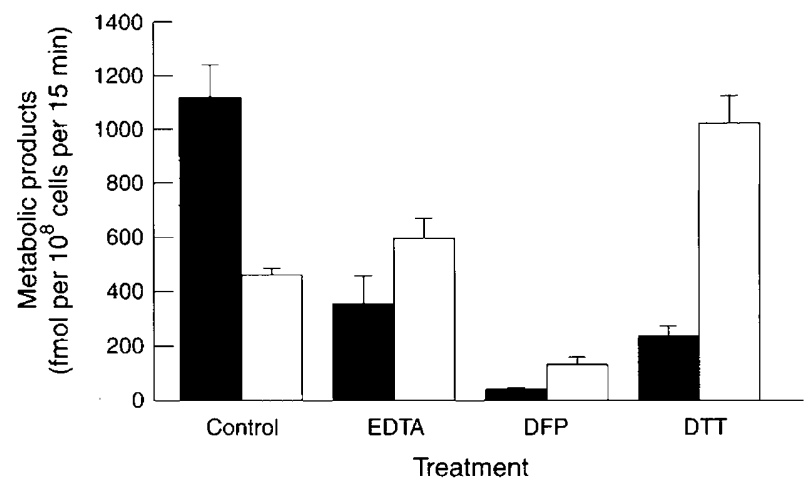

Fig. 1. Factors affecting the metabolism of exogenous $\left[{ }^{3} \mathrm{H}\right]$ plateletactivating factor (PAF) by rabbit endometrial tissue. Endometrial tissue was isolated on day 6 of pregnancy and incubated at $37^{\circ} \mathrm{C}$ for $60 \mathrm{~min}$ before approximately $30 \mathrm{mg}$ (wet mass) of the cell suspension was taken for incubation with $5 \mu \mathrm{Ci}\left[{ }^{3} \mathrm{H}\right] \mathrm{PAF}$ for $15 \mathrm{~min}$ at $37^{\circ} \mathrm{C}$. Incubation was carried out either in Tris- $\mathrm{HCl}$ buffer $(\mathrm{pH} 7)$ without any additives or in the presence of EDTA ( $10 \mathrm{mmol} \mathrm{l}^{-1}$ ), diisopropylfluorophosphate (DFP; $10 \mathrm{mmol} \mathrm{l}^{-1}$ ) or dithiothreitol (DTT; $10 \mathrm{mmol}$ $1^{-1}$ ). Extraction of total lipids, detection of lipids by TLC, and estimation of cellular DNA content (normalized to number of cells; each cell contains approximately $10 \mathrm{pg}$ DNA) were performed. The experiments expressed in this figure were conducted at the same time as those described in Figs 2 and 3. They have been presented separately for simplicity. The control treatment groups are identical. a), Lyso-PAF; ( $\square$ ), Alkylacyl-GPC.

Newman-Keuls' tests of significance were performed using the SAS computer program (SAS Institute Inc., Cary, NC). Differences of $P<0.05$ were considered significant.

\section{Results}

\section{P H]Platelet-activating factor uptake by endometrial tissues}

As early as 1 min after incubation of the endometrial tissues with [ $\left.{ }^{3} \mathrm{H}\right] \mathrm{PAF}$, only $40 \%$ of the radioactivity could be recovered in the supernatant after three washes with $0.25 \%$ BSA in Tris- $\mathrm{HCl}$ buffer. Of the $60 \%$ associated with the cells, $54 \%$ was found in the cytosol and only $4 \%$ associated with the plasma membranes that were recovered after centrifugation at $30000 \mathrm{~g}$ for $30 \mathrm{~min}$. The amount of radioactivity associated with the cells increased to $74 \%$ after incubation for $60 \mathrm{~min}$, and only $6 \%$ was bound to the plasma membranes. This observation confirmed that exogenous $\left[{ }^{3} \mathrm{H}\right] \mathrm{PAF}$ was transported into the cells during incubation.

\section{Platelet-activating factor metabolism by unprimed endometrial tissues}

In the present series of experiments, $5 \mu \mathrm{Ci}\left[{ }^{3} \mathrm{H}\right] \mathrm{PAF}$ was used to provide excess substrate for about $30 \mathrm{mg}$ endometrial tissue per tube and control untreated endometrial cells metabolized the exogenous $\left[{ }^{3} \mathrm{H}\right] \mathrm{PAF}$ first into $\left[{ }^{3} \mathrm{H}\right] \mathrm{lyso}-\mathrm{PAF}$ and subsequently $\left[{ }^{3} \mathrm{H}\right]$ alkylacyl-GPC (Fig. 1): the amount of $\left[{ }^{3} \mathrm{H}\right]$ lyso-PAF build-up was about 2.5 -fold the quantity of $\left[^{3} \mathrm{H}\right]$ alkylacyl-GPC. In the presence of $0.25 \% \mathrm{BSA},\left[{ }^{3} \mathrm{H}\right] \mathrm{PAF}$ metabolism was 
completely abolished (data not shown) as we have observed using purified endometrial membranes (Kudolo and Harper, 1990). Therefore, all ligands were solubilized in $70 \%$ ethanol and the ethanol final concentration in the reaction mixture did not exceed $0.875 \%$. Endometrial $\left[{ }^{3} \mathrm{H}\right] \mathrm{PAF}$ deacetylation was apparently catalysed mainly by cytosolic acetylhydrolase because pretreatment of the cells with $10 \mathrm{mmol}$ DFP $\mathrm{l}^{-1}$, a protease inhibitor of serine hydrolases, abrogated over $98 \%$ of $\left[{ }^{3} \mathrm{H}\right] \mathrm{PAF}$ metabolism. In the presence of the calcium-chelating agent, EDTA, the amount of $\left[{ }^{3} \mathrm{H}\right] \mathrm{lyso}$-PAF formed was significantly reduced by $70 \%$ without any significant change in accumulation of $\left[{ }^{3} \mathrm{H}\right]$ alkylacyl-GPC. The presence of DTT also caused a significant reduction in lyso-PAF concentration but, unlike treatment with EDTA, this was accompanied by an increased accumulation of $\left[{ }^{3} \mathrm{H}\right]$ alkylacyl-GPC, $118 \%$ greater than in the control. There was no apparent reconversion of the metabolic products back to $\left[{ }^{3} \mathrm{H}\right] \mathrm{PAF}$. Instead, there was an apparent loss of radioactivity not accountable for when the radioactivity co-migrating with PAF, lyso-PAF and alkylacylGPC was combined. This residual radioactivity was detected in conjunction with a lipid product migrating to the solvent front when chromatographed in chloroform:methanol:acetic acid: water (50:25:8:4). The lipid co-migrated with the product of phospholipase $\mathrm{C}$ digestion of $\left[{ }^{3} \mathrm{H}\right] \mathrm{PAF}$ when chromatographed in a solvent system consisting of chloroform and methanol (98:2) and with authentic 1-O-hexadecyl-2-acetyl-rac-glycerol. This neutral lipid accounted for up to $30 \%$ of the radioactivity added. Phospholipase $\mathrm{C}$ digestion of $\left[{ }^{3} \mathrm{H}\right]$ lyso-PAF did not yield a neutral lipid and the radioactivity remained at the origin.

\section{Effect of $\mathrm{N}$-carbamyl-platelet-activating factor on platelet-activating factor metabolism}

The possible effect of high PAF concentration on the endometrial handling of exogenous $\left.{ }^{3} \mathrm{H}\right] \mathrm{PAF}$ at a time when the endogenous concentrations are falling was examined by treating endometrial tissues from day 6 of pregnancy with graded doses of $N$-carbamyl-PAF for $1 \mathrm{~h}$ at $37^{\circ} \mathrm{C}$ before addition of exogenous $\left[{ }^{3} \mathrm{H}\right] \mathrm{PAF}$. Increasing concentration of carbamyl-PAF from $10 \mathrm{nmol} 1^{-1}$ to $10 \mu \mathrm{mol} 1^{-1}$ was accompanied by decreased $\left[^{3} \mathrm{H}\right]$ lyso-PAF accumulation, so that at $10 \mu \mathrm{mol} \mathrm{l}^{-1}$, only $14 \%$ of the amount found in the control cells remained (Fig. 2a). The concentration of $\left[{ }^{3} \mathrm{H}\right]$ alkylacyl-GPC was also reduced in parallel with $\left.{ }^{3} \mathrm{H}\right] \mathrm{lys}-\mathrm{PAF}$ up to $1 \mu \mathrm{mol}$ $\mathrm{N}$-carbamyl-PAF ${ }^{-1}$. At $10 \mu \mathrm{mol}^{-1}$, however, a significantly higher concentration of ${ }^{3} \mathrm{H}$ lalkylacyl-GPC accumulation was observed, and this increase was accompanied by a reduced $\left[{ }^{3} \mathrm{H}\right]$ lyso-PAF build-up. Increasing the concentration of $\mathrm{N}$-carbamyl-PAF resulted in a corresponding increase in the radioactivity of the lipid that co-migrated with authentic PAF (Fig. 2b).

\section{Effect of calcium on platelet-activating factor metabolism}

The role of both intracellular and extracellular calcium on PAF metabolism was examined, since the presence of the calcium chelator, EDTA, caused a $70 \%$ reduction in the accumulation of $\left[{ }^{3} \mathrm{H}\right]$ lyso-PAF (Fig. 1). The presence of
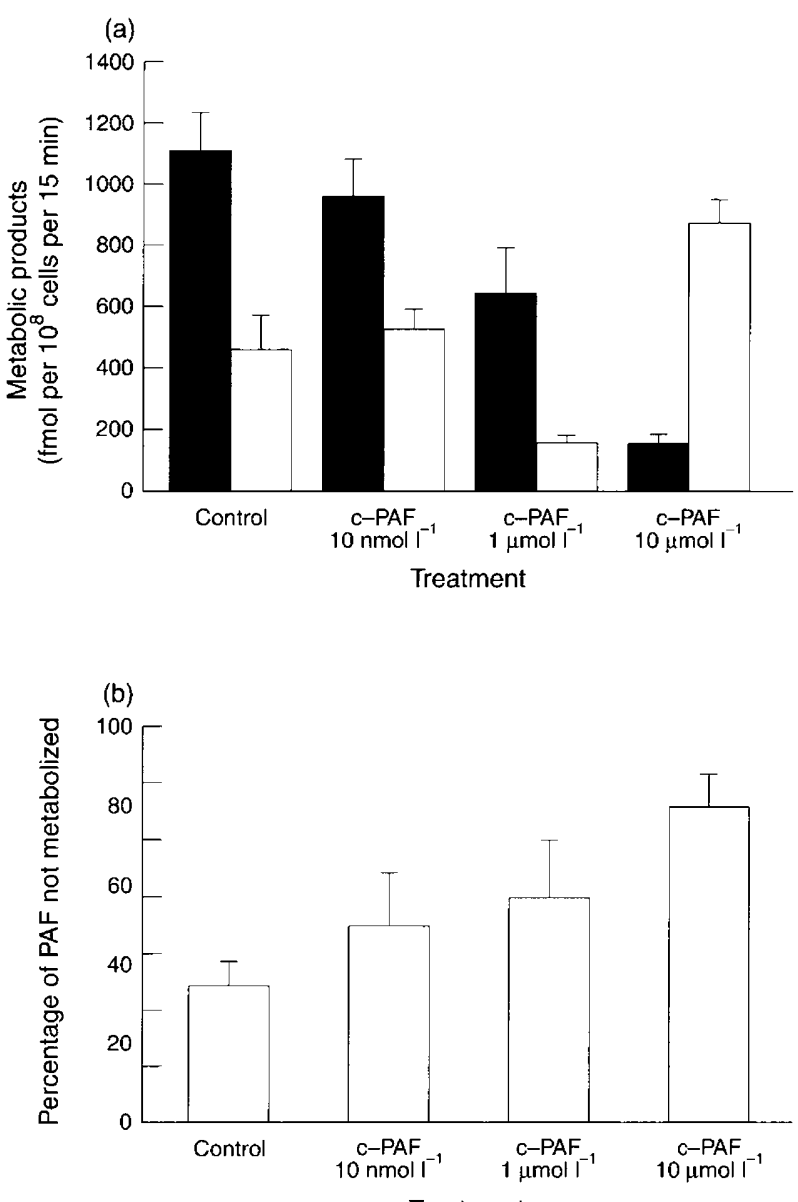

Fig. 2. Effect of carbamyl-platelet activating factor (PAF) on rabbit endometrial tissue metabolism of exogenous $\left[{ }^{3} \mathrm{H}\right] \mathrm{PAF}$. Endometrial tissue was incubated in plain Tris- $\mathrm{HCl}$ buffer ( $\mathrm{pH} \mathrm{7;} \mathrm{control)} \mathrm{or}$ different concentrations of carbamyl-PAF (c-PAF; solubilized in $70 \%$ ethanol; final concentration $<1 \%$ ethanol per tube) for $60 \mathrm{~min}$ at $37^{\circ} \mathrm{C}$. Duplicate aliquots of the cell suspensions with approximately $30 \mathrm{mg}$ (wet mass) of cells were incubated with $5 \mu \mathrm{Ci}\left[{ }^{3} \mathrm{H}\right] \mathrm{PAF}$ for $15 \mathrm{~min}$ at $37^{\circ} \mathrm{C}$. Total lipids were extracted and chromatographed, and the DNA content of the cells per tube estimated. The experiments were repeated three times. (a) The amounts of $\left[{ }^{3} \mathrm{H}\right] \mathrm{lyso}-\mathrm{PAF}$ (回) and $\left[{ }^{3} \mathrm{H}\right]$ alkylacyl-GPC $(\square)$ detected. (b) The percentages of unmetabolized $\left[{ }^{3} \mathrm{H}\right] \mathrm{PAF}$ (defined as the ratio of radioactivity co-migrating with authentic $\mathrm{C} 18 \mathrm{PAF}$ to the total radioactivity $\left(\left[{ }^{3} \mathrm{H}\right] \mathrm{PAF}\right)$ added $\times 100$ ).

$10 \mathrm{mmol}$ extracellular $\mathrm{CaCl}_{2} \mathrm{I}^{-1}\left(\left[\mathrm{Ca}^{2+}\right]_{\mathrm{o}}\right)$ produced a modest reduction in $\left[^{3} \mathrm{H}\right]$ lyso-PAF accumulation (30\%), accompanied by $170 \%$ increase in $\left[{ }^{3} \mathrm{H}\right]$ alkylacyl-GPC production over values obtained in the absence of $\mathrm{Ca}^{2+}$ (Fig. 3). In the presence of EGTA, another calcium chelator, however, there was more than a threefold increase in the build-up of $\left[{ }^{3} \mathrm{H}\right] \mathrm{lys}$-PAF, and about a twofold increase in $\left[{ }^{3} \mathrm{H}\right]$ alkylacyl-GPC accumulation, an indication of a pronounced calcium-dependent $\left.{ }^{3} \mathrm{H}\right] \mathrm{PAF}$ metabolism by the cells. This is confirmed by the fact that cell treatment with calcium ionophore A23187, in the absence of extracellular $\mathrm{Ca}^{2+}$ in the buffer, did not produce significant changes in the accumulation of the metabolic products. 


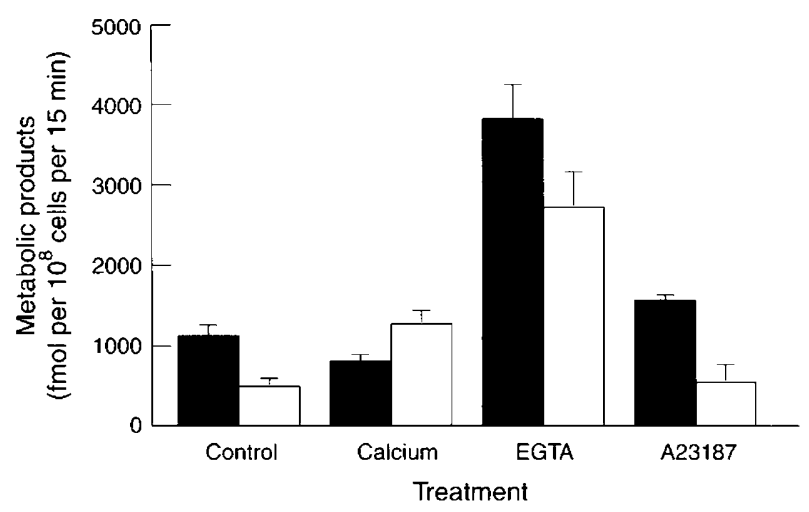

Fig. 3. The role of calcium in the metabolism of exogenous $\left[{ }^{3} \mathrm{H}\right]$ platelet-activating factor (PAF). Rabbit endometrial tissue was preincubated in Tris- $\mathrm{HCl}$ buffer containing $\mathrm{CaCl}_{2}\left(10 \mathrm{mmol} \mathrm{I}^{-1}\right)$, EGTA (10 $\mathrm{mmol} \mathrm{I}^{-1}$ ) or calcium ionophore $\mathrm{A} 23187\left(10 \mu \mathrm{mol} \mathrm{I}{ }^{-1}\right)$, or plain Tris- $\mathrm{HCl}$ buffer (control) for $60 \mathrm{~min}$ before addition of $5 \mu \mathrm{Ci}\left[{ }^{3} \mathrm{H}\right] \mathrm{PAF}$ and incubation for a further $15 \mathrm{~min}$ at $37^{\circ} \mathrm{C}$. Total lipids were extracted and chromatographed. The DNA content of the cells per tube was estimated. The experiments were conducted three times in duplicate. (ם), Lyso-PAF; ( $\square$ ), Alkylacyl-GPC.

\section{Synthesis and identity of neutral lipid product}

A neutral lipid product was synthesized during the metabolism of exogenous $\left[{ }^{3} \mathrm{H}\right] \mathrm{PAF}$. It appeared initially that the neutral lipid was synthesized subsequent to $\left[{ }^{3} \mathrm{H}\right] \mathrm{PAF}$ deacetylation and not directly from the added $\left[{ }^{3} \mathrm{H}\right] \mathrm{PAF}$, and yet phospholipase $\mathrm{C}$ digestion of $\left[{ }^{3} \mathrm{H}\right] \mathrm{PAF}$, but not $\left[{ }^{3} \mathrm{H}\right]$ lyso-PAF, produced the neutral lipid, which co-migrated with 1-Ohexadecyl-acetyl-glycerol (Fig. 4). Therefore, the neutral lipid produced when endometrial cells were incubated with $\left[{ }^{3} \mathrm{H}\right]$ lysoPAF $(5 \mu \mathrm{Ci})$ for $15 \mathrm{~min}$, and enhanced when a microsomal preparation (from endometrial tissues) was added, must have been produced after $\left[{ }^{3} \mathrm{H}\right]$ lyso-PAF reacetylation to $\left[{ }^{3} \mathrm{H}\right] \mathrm{PAF}$. We have shown that this neutral lipid was identical to the lipid product of PAF incubation with phospholipase $\mathrm{C}$ (Kudolo and Harper, 1995). In addition to this, after TLC and using GC/FID, the neutral lipid extracted from the glandular epithelial cell incubation medium was found to be eluted at $11.7 \mathrm{~min}(n=2)$, which was not different from that for the lipid produced by

Fig. 4. Chromatographic profile of phospholipase $C$-catalysed neutral lipid synthesis from platelet-activating factor (PAF). $\left[^{3} \mathrm{H}\right] \mathrm{PAF}$ and $\left[{ }^{3} \mathrm{H}\right]$ lyso-PAF $(5 \mu \mathrm{Ci})$ were added to $200 \mu \mathrm{g}$ of cold PAF and lysoPAF, dried under a stream of nitrogen gas and solubilized in $0.5 \mathrm{ml}$ $0.125 \%(\mathrm{w} / \mathrm{v}) \mathrm{BSA}$ in Tris- $\mathrm{HCl}$ buffer (containing $25 \mathrm{mmol} \mathrm{Ca}{ }^{2+} \mathrm{I}^{-1}$ ) and incubated with $10 \mu \mathrm{g}$ phospholipase $\mathrm{C}$ for $1 \mathrm{~h}$ at $37^{\circ} \mathrm{C}$. The reaction product was extracted by the method of Bligh and Dyer (1959). (a) and (b) When chromatographed in chloroform:methanol: acetic acid:water (50:25:8:4), a lipid product migrating to the solvent front was produced from $\left[{ }^{3} \mathrm{H}\right] \mathrm{PAF}$, but not from $\left[{ }^{3} \mathrm{H}\right] \mathrm{lys}$ so-PAF, and also from extracts of $\left[{ }^{3} \mathrm{H}\right] \mathrm{PAF}$ metabolism by rabbit glandular epithelial but not by stromal cells (see Fig. 7). (c) and (d) The lipid co-migrated with the product of phospholipase $\mathrm{C}$ digestion of $\left[{ }^{3} \mathrm{H}\right] \mathrm{PAF}$ and authentic 1-O-hexadecyl-2-acetyl-glycerol when chromatographed in a solvent system consisting of chloroform and methanol (98:2). (a) and (c) (ם), PAF alone; ( $\square$ ), PAF + phospholipase $C$; (b) and

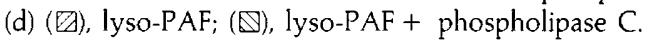

phospholipase $C$ digestion of PAF, which was $11.5 \pm 1.6 \mathrm{~min}$ (mean $\pm \mathrm{SD}, n=3$ ).

Platelet-activating factor metabolism by subcellular fractions of endometrial cells

After demonstrating that an appreciable amount of $\left[^{3} \mathrm{H}\right] \mathrm{PAF}$ was transported into the endometrial cells within $5 \mathrm{~min}$ of

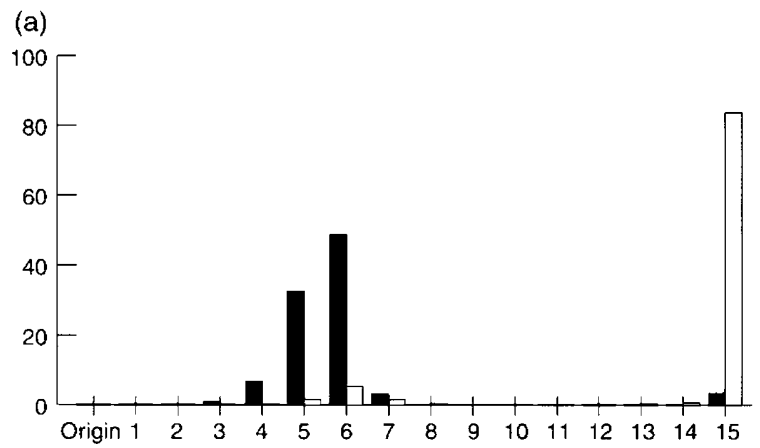

(b)

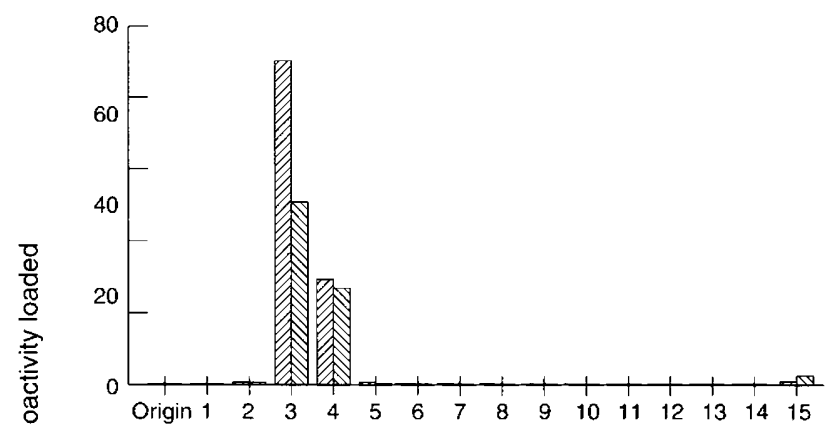

(c)

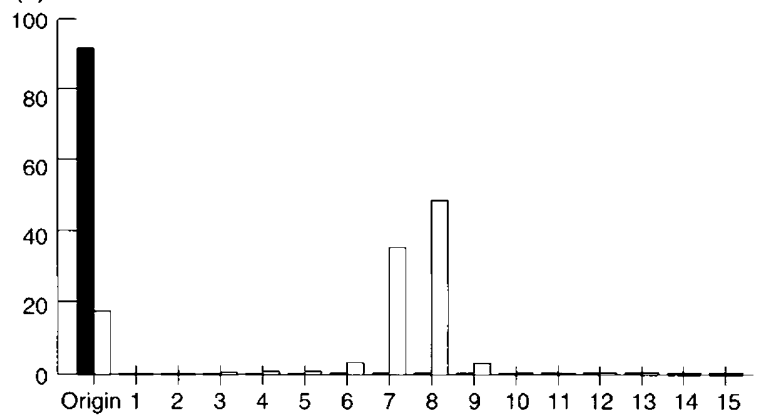

(d)

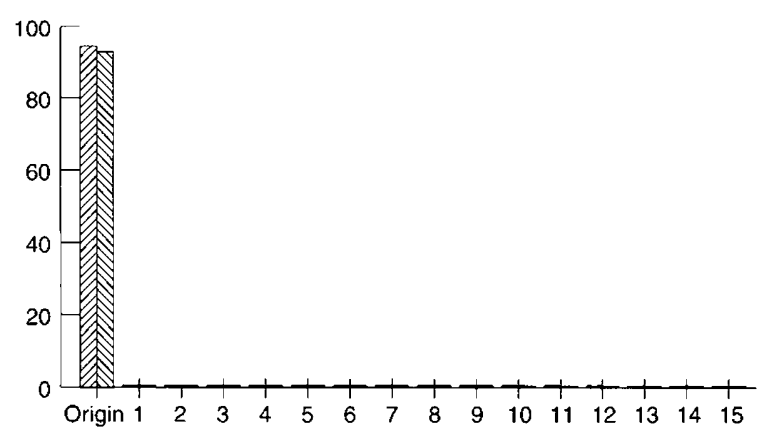


incubation, and that DFP ( $10 \mathrm{mmol} \mathrm{l}^{-1}$ ) abolished its metabolism, indicative of acetylhydrolase activity, it remained to confirm these observations with isolated subcellular fractions. Only the cytosolic fraction avidly metabolized $\left[{ }^{3} \mathrm{H}\right] \mathrm{PAF}$, with less than $10 \%$ of the native $\left[{ }^{3} \mathrm{H}\right] \mathrm{PAF}$ remaining after $30 \mathrm{~min}$ of incubation (Fig. 5). The formation of alkylacyl-GPC in the cytosol, also observed in the human platelet cytosol by Kramer et al. (1984), may be due to the leakage of membraneassociated transacylase enzymes into the cytosol during tissue homogenization. Neither the membranes nor the microsomes metabolized [ $\left.{ }^{3} \mathrm{H}\right] \mathrm{PAF}$, but both avidly metabolized $\left[{ }^{3} \mathrm{H}\right] \mathrm{lyso}$ PAF, over $80 \%$ by the membranes and $40 \%$ by the microsomes within $5 \mathrm{~min}$ (Fig. 6).

\section{Platelet-activating factor metabolism by cultured endometrial cells}

Separated endometrial cells were cultured to examine whether the different cell types metabolized exogenous $\left[{ }^{3} \mathrm{H}\right] \mathrm{PAF}$ similarly. Addition of $\left.4 \mathrm{nmol}\left[{ }^{3} \mathrm{H}\right] \mathrm{PAF}\right]^{-1}$ on day 2 of culture produced the results shown in Fig. 7. Within $5 \mathrm{~min}$, $\left[{ }^{3} \mathrm{H}\right] \mathrm{PAF}$ was metabolized via distinct pathways: there was significantly more $\left[{ }^{3} \mathrm{H}\right]$ lyso-PAF accumulation in stromal cells than in epithelial cells. The radioactivity that could not be accounted for by the sum of $\left[{ }^{3} \mathrm{H}\right]$ lyso-PAF and $\left[{ }^{3} \mathrm{H}\right]$ alkylacylGPC in the epithelial cells was again found to be converted to a neutral lipid.

\section{Discussion}

A principal observation from these experiments was that the metabolism of exogenous [ $\left.{ }^{3} \mathrm{H}\right] \mathrm{PAF}$ took place after it had traversed the cell membrane and come into contact with cytosolic acetylhydrolase. Almost $60 \%$ of added $\left[{ }^{3} \mathrm{H}\right] \mathrm{PAF}$ was in the cytosolic fraction of the cell within $5 \mathrm{~min}$. Once inside the cell, [ $\left.{ }^{3} \mathrm{H}\right] \mathrm{PAF}$ metabolism appears to have been accomplished by the sequential action of two enzymes. The first step was catalysed by acetylhydrolase in the cytosolic fraction that deacetylates $\left[{ }^{3} \mathrm{H}\right] \mathrm{PAF}$ forming $\left[{ }^{3} \mathrm{H}\right]$ lyso-PAF. This step was independent of calcium stimulation. Calcium appeared to be inhibitory because $\left[{ }^{3} \mathrm{H}\right] \mathrm{PAF}$ metabolism was enhanced over three times in the presence of EGTA. The second step was catalysed by a membrane-associated transacylase enzyme that incorporates a long-chain fatty acid into $\left[{ }^{3} \mathrm{H}\right]$ lyso-PAF to produce $\left[{ }^{3} \mathrm{H}\right.$ ]alkylacyl-GPC, in agreement with other cell systems (Blank et al., 1981; Albert and Snyder, 1983; Kramer et al., 1984). However, in addition to $\left[{ }^{3} \mathrm{H}\right]$ alkylacyl-GPC formation, there was also the formation of a neutral lipid, the synthesis of

Fig. 5. $\left[{ }^{3} \mathrm{H}\right]$ platelet-activating factor (PAF) metabolism by subcellular fractions of rabbit endometrial tissue. Endometrial tissues were fractionated into plasma membranes, cytosol and microsomes as described in the Materials and Methods. Portions (50 $\mu \mathrm{g}$ protein) were incubated with $4 \mathrm{nmol}\left[^{3} \mathrm{H}\right] \mathrm{PAF} \mathrm{I}^{-1}$ at $37^{\circ} \mathrm{C}$ and the reaction terminated after 1 , 5,15 and $30 \mathrm{~min}$. The lipids were extracted by the Bligh and Dyer (1959) procedure and chromatographed. The experiments, in triplicate, were performed only twice, but with less than $10 \%$ variation between the means. (a) Membrane; (b) Microsomes; (c) Buffer; and (d) Cytosol. (a), PAF; (_), Lyso-PAF; (o), Alkylacyl-GPC. which was catalysed by a microsomal enzyme found in the glandular epithelial, but not in the stromal, cells. We have provided the first documentation of the cell-specific synthesis

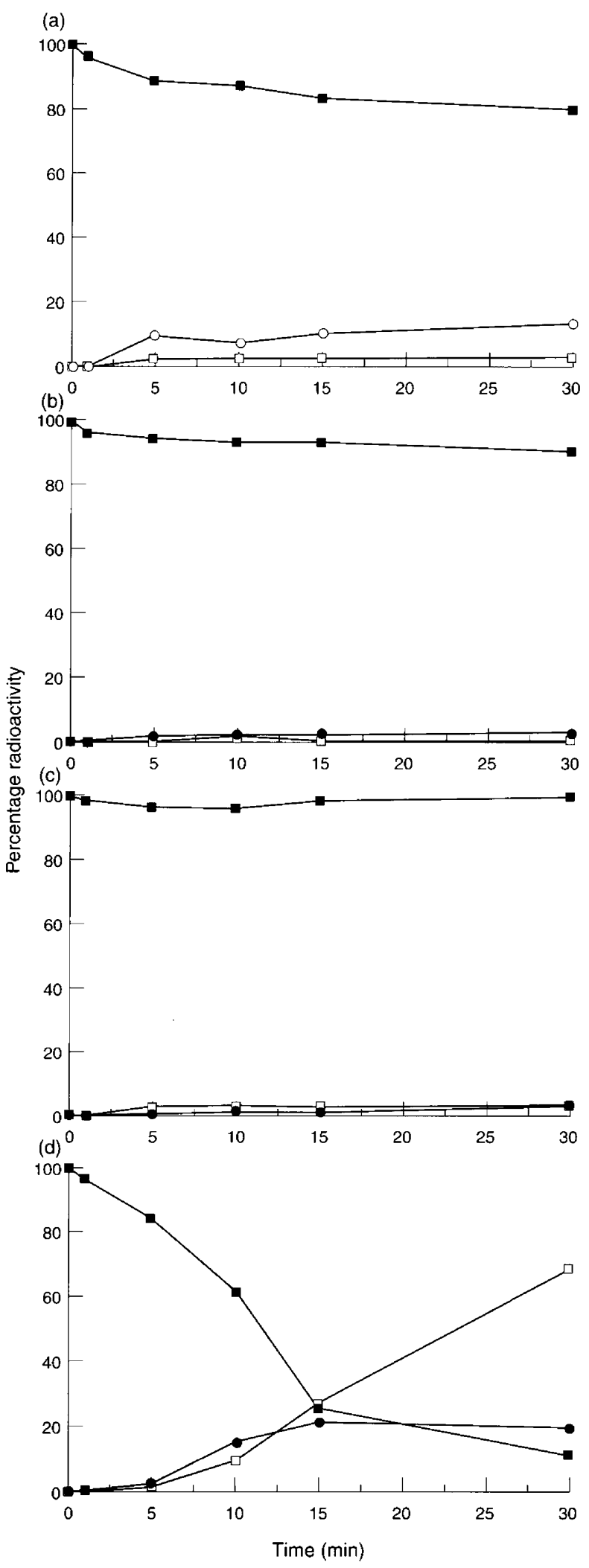


(a)

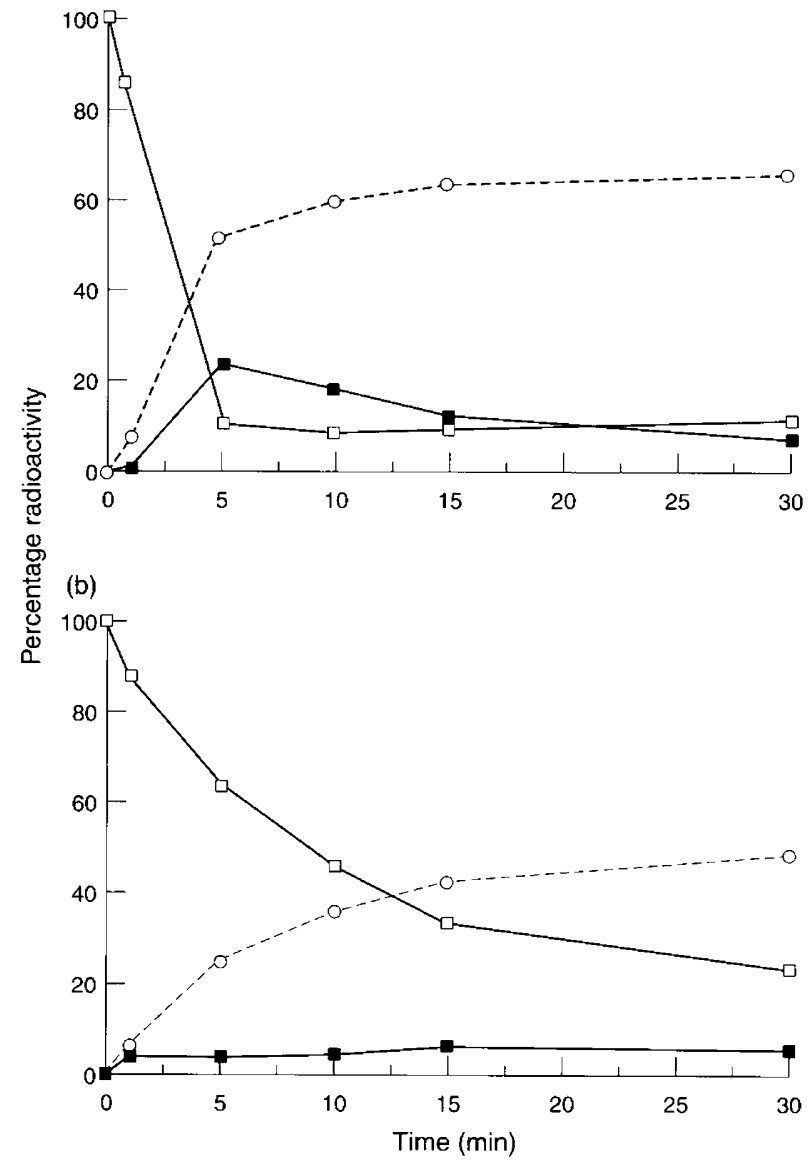

Fig. 6. $\left[{ }^{3} \mathrm{H}\right]$ lyso-PAF metabolism by (a) membrane and (b) microsomal fractions of rabbit endometrial tissue. Membrane and microsomal fractions were prepared and incubated with $4 \mathrm{nmol}\left[{ }^{3} \mathrm{H}\right] \mathrm{lyso}-\mathrm{PAF} \mathrm{l}^{-1}$. The lipids were extracted by the Bligh and Dyer (1959) procedure and chromatographed. The experiments, in triplicate, were performed only twice, but with less than 10\% variation between the means. ( platelet-activating factor (PAF); (๘), Lyso-PAF; (৩), Alkylacyl-GPC.

of this lipid in the mammalian endometrium (Kudolo and Harper, 1995). The present study demonstrated the ability of intact endometrial cells to metabolize exogenous $\left[{ }^{3} \mathrm{H}\right] \mathrm{PAF}$ and $\left[{ }^{3} \mathrm{H}\right]$ lyso-PAF, and in this regard rabbit endometrium may differ from other cell systems: for example $\left[{ }^{3} \mathrm{H}\right]$ lyso-PAF is poorly metabolized by intact rabbit platelets (Lachachi et al., 1985; Touqui et al., 1987) and by cultured rat Kupffer cells (Chao et al., 1989).

Our inability to observe significant PAF accumulation in rabbit endometrium was initially intriguing because similar incubation conditions had promoted PAF synthesis in other cells, and because it could have been produced merely from reacetylation of $\left[{ }^{3} \mathrm{H}\right]$ lyso-PAF. There are two different enzymes that can catalyse PAF synthesis: lyso-PAF:acetyl-CoA acetyltransferase (Wykle et al., 1980) and CDP-choline:1alkylacetylglycerol-DTT-insensitive cholinephosphotransferase (Renooij and Snyder, 1981). Biosynthesis of PAF is calcium dependent (Ninio et al., 1983); both EDTA and EGTA inhibit acetyltransferase activity (Wykle et al., 1980). However, treatment of mouse peritoneal cells with DTT results in a two-
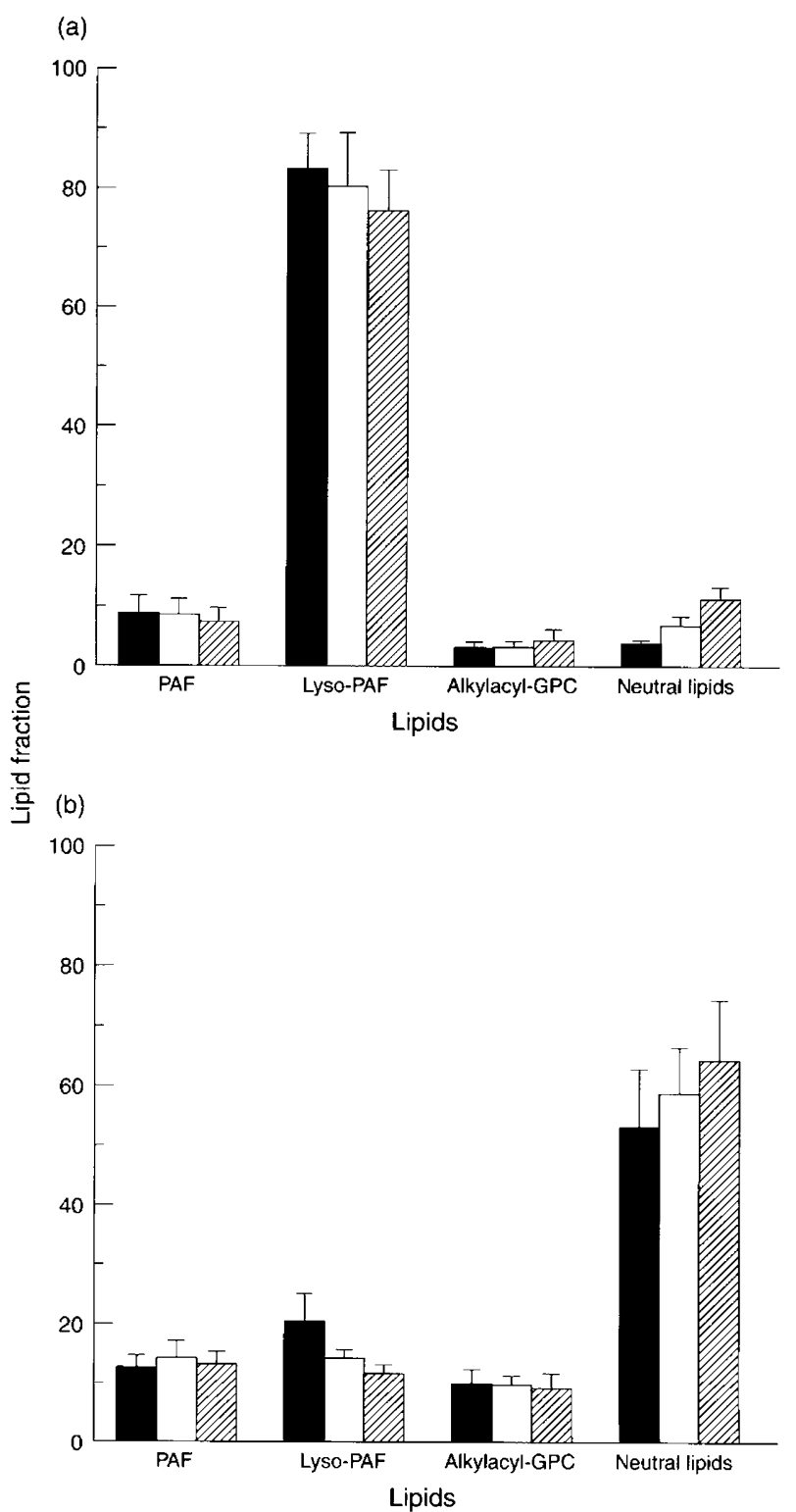

Fig. 7. Metabolism of exogenous $\left[{ }^{3} \mathrm{H}\right] \mathrm{PAF}$ by separated rabbit (a) endometrial stromal and (b) epithelial cell fractions. Endometrial cells were enzymatically separated into glandular epithelial and stromal cells and on the second day of culture, exogenous [ $\left.{ }^{3} \mathrm{H}\right] \mathrm{PAF}$ was added to the cells in $2 \mathrm{ml}$ culture medium (in the absence of calf serum) and incubation continued for $(\square), 15(\square), 30$ and ( $\square), 60 \mathrm{~min}$. Total lipids were extracted from the cells and medium and chromatographed in a solvent system consisting of chloroform:methanol:acetic acid:water $(50: 25: 8: 4)$. The neutral lipid that migrated to the solvent front in this system, co-migrated with 1-O-hexadecyl-2-acetyl-glycerol when chromatographed in chloroform:methanol (98:2). Experiments were performed at least three times, in triplicate wells.

threefold increase of acetyltransferase activity and corresponding PAF synthesis (Ninio, 1987). Lyso-PAF:acetyltransferase activity could have been activated in the endometrial cells without activation of PAF synthesis, as seen in cultured mast cells (Joly et al., 1990). Alternatively, PAF could have been produced and rapidly metabolized to lyso-PAF or the neutral 
lipid, depending on the cell type. We have demonstrated the incorporation of $\left[{ }^{3} \mathrm{H}\right]$ acetyl-CoA into exogenous lyso-PAF catalysed by a microsomal preparation from endometrial tissues (Kudolo and Harper, 1995). Therefore, the synthesis of the neutral lipid must have taken place subsequent to the reacetylation of lyso-PAF to PAF and its conversion via a phospholipase $C$-catalysed reaction, in agreement with observations made in cultured rat hepatocytes (Okayasu et al., 1986).

In rabbit endometrial cells in culture, PAF synthesis is essentially via the remodelling pathway (Kasamo et al., 1992). However, this may not be true for constitutive synthesis in vivo. In the stromal cells where no neutral lipid synthesis was observed, lyso-PAF:acetyl CoA:acetyltransferase activity, but not phospholipase $\mathrm{C}$, may be the limiting factor, hence the build-up of lyso-PAF. In the de novo pathway, neutral lipids may serve as precursors for the synthesis of PAF (Wykle et al., 1980; Blank et al., 1988; Lee et al., 1988), and since the neutral lipid synthesis was restricted to the glandular epithelial cells, it may be that this is the pathway of choice in these cells. Therefore, the increasing concentration of uterine PAF observed with increasing gestation in the preimplantation period (Angle et al., 1988) may be a reflection of the proliferation of the glandular epithelial cells. The increase in the amount of radioactivity co-migrating with authentic PAF after treatment of the endometrial cells with $N$-carbamyl-PAF could have been due to a displacement of $\left[{ }^{3} \mathrm{H}\right] \mathrm{PAF}$ from membrane sites preventing the $\left[{ }^{3} \mathrm{H}\right] \mathrm{PAF}$ molecule from being transported into the cell for further metabolism. We support that view because the PAF analogue-stimulated intracellular $\left[^{3} \mathrm{H}\right] \mathrm{PAF}$ resynthesis should have led to an increase in the synthesis of the neutral lipids, which did not take place in the endometrial cells. Pretreatment of human neutrophils with $N$-carbamyl-PAF has not been shown to cause any change in $\left[{ }^{3} \mathrm{H}\right] \mathrm{PAF}$ metabolism, but did stimulate PAF synthesis (Tessner et al., 1989). This latter observation could not be confirmed by Sisson et al. (1987). We have no evidence at this time that $N$-carbamyl-PAF treatment altered the number or occupancy of the endometrial surface membrane PAF receptors. We have reported only that $\left[{ }^{3} \mathrm{H}\right]-\mathrm{N}$-carbamyl-PAF binds with high affinity to purified endometrial membrane sites (Kudolo and Harper, 1989). It is possible that $\mathrm{N}$-carbamyl-PAF treatment alters the number or occupancy of these sites, as seen with myelogenous cells, in which it induced up to a $70 \%$ reduction in the number of binding sites without any effect of PAF metabolism (O'Flaherty et al., 1989).

Taken together, metabolism of exogenous PAF in short-term incubations may take place after it enters the endometrial cell. Once inside the cell, PAF is subject to rapid deacetylation. The fate of lyso-PAF is cell dependent. In the stroma, PAF synthesis may be limited and restricted to a remodelling pathway, and lyso-PAF:acetyl CoA acetyltransferase may be a limiting factor. The bulk of endogenous uterine PAF synthesis observed during the preimplantation period may take place in the glandular epithelial cells via a unique de novo pathway in which I-O-alkyl-2-acetyl-glycerol may serve as the substrate for CDP-choline:1-alkylacetylglycerol-DTT-insensitive cholinephosphotransferase (Renooij and Snyder, 1981; Kudolo and Harper, 1995) for PAF synthesis.

This work was supported by NIH grants HD 25224 and 14048 .

\section{References}

Abisogun AO, Braquet P and Tsafriri A (1989) The involvement of platelet activating factor in ovulation Science 243 381-383

Albert DH and Snyder F (1983) Biosynthesis of 1-O-alkyl-2-acetyl-sn-glycerophosphocholine by rat alveolar macrophages. Phospholipase $\mathrm{A}_{2}$ and acetyltransferase activities during phagocytosis and ionophore stimulation journal of Biological Chemistry 258 97-102

Alecozay AA, Casslén BG, Riehl RM, DeLeon FD, Harper MJK, Silva M, Nouchi TA and Hanahan DJ (1989) Role of platelet-activating factor (PAF) in human luteal phase endometrium Biology of Reproduction 41 578-586

Angle MJ, Jones MA, McManus LM, Pinckard RN and Harper MJK (1988) Platelet-activating factor in the rabbit uterus during early pregnancy Journal of Reproduction and Fertility 83 711-722

Benveniste J, Le Couedic JP, Plonsky J and Tencé M (1977) Structural analysis of purified platelet-activating factor by lipases Nature 269 170-171

Blank ML, Lee T-C, Fitzgerald V and Snyder F (1981) A specific acetylhydrolase for 1-alkyl-2-acetyl-sn-glycero-3-phosphocholine (a hypotensive and platelet-activating lipid) Journal of Biological Chemistry 256 175-178

Blank ML, Lee J, Cress EA and Snyder F (1988) Stimulation of the de novo pathway for the biosynthesis of platelet-activating factor (PAF) via cytidylyltransferase activation in cells with minimal endogenous PAF production Journal of Biological Chemistry 263 5656-5661

Bligh EG and Dyer WJ (1959) A rapid method of total lipid extraction and purification Canadian Journal of Biochemistry and Physiology 37 911-917

Burton K (1956) A study of the conditions and mechanism of the diphenylamine reaction for the colorimetric determination of deoxyribonucleic acid Biochemical Journal 62 315-323

Chao W, Siafaka-Kapadai A, Hanahan DJ and Olson MS (1989) Metabolism of platelet-activating factor (PAF; 1-O-alkyl-2-acetyl-sn-glycero-3-phosphocholine) and lyso-PAF (1-O-alkyl-2-lyso-sn-glycero-3-phosphocholine) by cultured rat Kupffer cells Biochemical journal 261 77-81

Harper MIK (1989) Platelet-activating factor: a paracrine factor in preimplantation stages of reproduction? Biology of Reproduction 40 907-913

Joly F, Vilgrain I, Bossant M-J, Bessou G, Benveniste J and Ninio E (1990) Biosynthesis of PAF-acether. Activators of protein kinase $C$ stimulate cultured mast cell acetyltransferase without stimulating PAF-acether synthesis Biochemical Journal 271 502-507

Kasamo M, Brandt M, Ishikawa M, Shimizu T and Harper MJK (1992) In vitro prostaglandin release from and platelet-activating factor accumulation in isolated endometrial cells from pregnant and pseudopregnant rabbits Biology of Reproduction 46 829-845

Kramer RM, Patton GM, Pritzker CR and Deykin D (1984) Metabolism of platelet-activating factor in human platelets. Transacylase-mediated synthesis of 1-O-alkyl-2-arachidonoyl-sn-glycero-3-phosphocholine fournal of Biological Chemistry 25913 316-13 320

Kudolo GB and Harper MJK (1989) Characterization of platelet-activating factor binding sites on uterine membranes from pregnant rabbits Biology of Reproduction 41 587-603

Kudolo GB and Harper MJK (1990) Estimation of platelet-activating factor receptors in the endometrium of the pregnant rabbit: regulation of ligand availability and catabolism by bovine serum albumin Biology of Reproduction $43 \quad 368--377$

Kudolo GB and Harper MJK (1995) Lyso-PAF:acetyl-CoA acetyltransferase and CDP-choline cholinephosphotransferase activities in the rabbit endometrium Joumal of Lipid Mediators and Cell Signalling 11 145-158

Lachachi H, Plantavid M, Simon MF, Chap H, Braquet P and Douste-Blazy L (1985) Inhibition of transmembrane movement and metabolism of plateletactivating factor (PAF-acether) by a specific antagonist, BN 52021 Biochemical and Biophysical Research Communications 132 460-466

Lee T-C, Malone B and Snyder F (1986) A new de novo pathway for the formation of 1-alkyl-2-acetyl-sn-glycerols, precursors of platelet-activating factor. Biochemical characterization of 1-alkyl-2-lyso-sn-glycerol-3-P:acetyl $\mathrm{CoA}$ acetyltransferase in rat spleen Journal of Biological Chemistry $\mathbf{2 6 1}$ 5373-5377

Lee T-C, Malone B and Snyder F (1988) Formation of I-alkyl-2-acetyl-snglycerols via the de novo biosynthetic pathway for platelet-activating factor. Characterization of 1-alkyl-2-acetyl-sn-glycero-3-phosphate phosphohydrolase in rat spleens Journal of Biological Chemistry 263 1755-1760

Maggi M, Bonaccorsi L, Finetti G, Carloni V, Muratori M, Laffi G, Forti G, Serio M and Baldi E (1994) Platelet-activating factor mediates an autocrine proliferative loop in the endometrial adenocarcinoma cell line HEC-1A Cancer Research 54 4777-4784 
Ninio E (1987) Regulation of platelet-activating factor-acether biosynthesis in various cell types. In New Horizons in Platelet Activating Factor Research pp 27-35 Eds CM Winslow and ML Lee. John Wiley \& Sons Ltd New York

Ninio E, Mencia-Huerta J and Benveniste J (1983) Biosynthesis of plateletactivating factor (PAF-acether). V. Enhancement of acetyltransferase activity in murine peritoneal cells by calcium ionophore A23187 Biochimica et Biophysica Acta 751 298-304

O'Flaherty JT, Chabot MC, Redman J, Jr, Jacobson D and Wykle RL (1989) Receptor-independent metabolism of platelet-activating factor by myelogenous cells FEBS Letters 250 341-344

Okayasu T, Hoshii K, Seyama K, Ishibashi T and Imai Y (1986) Metabolism of platelet-activating factor in primary cultured adult rat hepatocytes by a new pathway involving phospholipase $\mathrm{C}$ and alkyl monooxygenase Biochimica et Biophysica Acta 876 58-64

O'Neill C (1987) Embryo-derived platelet-activating factor: a preimplantation embryo mediator of maternal recognition of pregnancy Domestic Animal Endocrinology $4907-914$

O'Neill C, Gidley-Baird AA, Pike IL and Saunders DM (1987) Use of a bioassay for embryo-derived platelet-activating factor as a means of assessing quality and pregnancy potential of human embryos Fertility and Sterility 47 969-975

Renooij W and Snyder F (1981) Biosynthesis of 1-alkyl-2-acetyl-sn-glycero-3phosphocholine (platelet-activating factor and a hypotensive lipid) by cholinephosphotransferase in various rat tissues Biochimica et Biophysica Acta $663545-556$

Ricker DD, Minhas BS, Kumar R, Robertson JL and Dodson MG (1989) The effect of platelet-activating factor on the motility of human spermatozoa Fertility and Sterility 52 655-658

Ricketts AP, Hagensee M and Bullock DW (1983) Characterization in primary monolayer culture of separated cell types from rabbit endometrium Journal of Reproduction and Fertility 67 151-160

Robinson M, Blank ML and Snyder F (1985) Acylation of lysophospholipids by rabbit alveolar macrophages. Specificities of CoA-dependent and CoA-independent reactions Journal of Biological Chemistry $2607889-7895$
Sisson JH, Prescott SM, McIntyre TM and Zimmerman GA (1987) Production of platelet-activating factor by stimulated human polymorphonuclear leukocytes. Correlation of synthesis with release, functional events, and leukotriene $\mathrm{B}_{a}$ metabolism Journal of Immunology $1383918-3926$

Snyder F (1990) Platelet-activating factor and related acetylated lipids as potent biologically active cellular mediators American Journal of Physiology (Cell Physiology) 259 C697-C708

Snyder F, Lee T-C and Blank ML (1989) Platelet-activating factor and related ether lipid mediators. Biological activities, metabolism, and regulation Annals of the New York Academy of Sciences $56835-43$

Tessner TG, O'Flaherty JT and Wykle RL (1989) Stimulation of plateletactivating factor synthesis by a nonmetabolizable bioactive analog of platelet-activating factor and influence of arachidonic acid metabolites Journal of Biological Chemistry 264 4794-4799

Touqui L, Jacquemin CJ, Dumarey C and Vargaftig BB (1985) 1-O-alkyl-2-acylsn-glycero-3-phosphorylcholine is the precursor of platelet-activating factor in stimulated rabbit platelets. Evidence for an alkylacetyl-glycerophosphorylcholine cycle Biochimica ef Biophysica Acta 833 111-118

Touqui L, Shaw AM, Dumarey C, Jacquemin C and Vargaftig BB (1987) The role of $\mathrm{Ca}^{2+}$ in regulating the catabolism of PAF-acether (1-O-aklyl-2-acetyl-snglycero-3-phosphocholine) in rabbit platelets Biochemical Journal $241555-$ 560

Triolo A, Bertini J, Mannucci C, Perico A and Pestellini V (1991) Analysis of platelet-activating factor by gas chromatography-mass spectroscopy: low energy electron impact of the corresponding 3-acetyl-2-tert.butyldimethylsilyl derivative Journal of Chromatography 568 281-290

Uemura Y, Lee T-C and Snyder F (1991) A coenzyme A-independent transacylase is linked to the formation of platelet-activating factor (PAF) by generating the lyso-PAF intermediate in the remodeling pathway Journal of Biological Chemistry $2668268-8272$

Wykle RL, Kraemer WF and Schremmer JM (1980) Specificity of lysophospholipase D Biochimica et Biophysica Acta $61958-67$

Yasuda K, Satouchi K and Saito K (1986) Platelet-activating factor in normal rat uterus Biochimica ef Biophysica Acta 138 1231-1236 